\title{
Role of asymptomatic bacteriuria on early periprosthetic joint infection after Hip Hemiarthroplasty. BARIFER randomized clinical trial.
}

Dolors Rodriguez-Pardo ( $\nabla$ dolorodriguez@vhebron.net)

Hospital Universitari Vall d'Hebron. https://orcid.org/0000-0001-6781-5405

María Dolores Del Toro

Virgen Macarena University Hospital: Hospital Universitario Virgen Macarena

Laura Guio Carrión

Cruces University Hospital: Hospital Universitario Cruces

\section{Rosa Escudero}

Ramon y Cajal University Hospital: Hospital Universitario Ramon y Cajal

Marta Fernández-Sampedro

Hospital Universitario Marques de Valdecilla

Miguel Ángel García Viejo

Puerta del Hierro University Hospital of Majadahonda: Hospital Universitario Puerta del Hierro

Majadahonda

María Velasco Arribas

Fundación Alcorcón University Hospital

Laura Soldevila-Boixader

Bellvitge University Hospital: Hospital Universitari de Bellvitge

Magdalena Femenias

Son Espases University Hospital: Hospital Universitari Son Espases

José Antonio Iribarren

Donostia Ospitalea: Hospital Universitario de Donostia

María del Carmen Pulido-Garcia

Hospital de la Santa Creu i Sant Pau

\section{$M^{a}$ Dolores Navarro}

Virgen Macarena University Hospital: Hospital Universitario Virgen Macarena

Mayli Lung

Vall d'Hebron Hospital: Vall d'Hebron Hospital Universitari

\section{Pablo S Corona}

Vall d'Hebron Hospital: Vall d'Hebron Hospital Universitari

\section{Benito Almirante}

Vall d'Hebron Hospital: Vall d'Hebron Hospital Universitari 


\section{Carles Pigrau}

Vall d'Hebron Hospital: Vall d'Hebron Hospital Universitari

\section{Original Article}

Keywords: Asymptomatic Bacteriuria, Fosfomycin-trometamol, Early-periprosthetic Joint Infection, Hip Hemiarthroplasty

Posted Date: March 1st, 2021

DOl: https://doi.org/10.21203/rs.3.rs-203528/v1

License: (c) (1) This work is licensed under a Creative Commons Attribution 4.0 International License. Read Full License

Version of Record: A version of this preprint was published at European Journal of Clinical Microbiology \& Infectious Diseases on April 16th, 2021. See the published version at https://doi.org/10.1007/s10096021-04241-2. 


\section{Abstract}

Purpose: To evaluate preoperative asymptomatic bacteriuria (ASB) treatment on the reduction of earlyperiprosthetic joint infections (early-PJIs) after hip hemiarthroplasty (HHA) for fracture.

Methods: Open-label, multicentre RCT comparing 3gr of fosfomycin-trometamol with non-treatment. A parallel follow-up cohort without ASB was established. Primary outcome: early-PJI within 3 months after HHA.

Results: 594 patients enrolled (mean age 84.3years); 152(25\%) with ASB (77 treated with fosfomycin and 75 controls) and 442(75\%) without. ASB was not a predictor of early-PJI (OR:1.06[95\%Cl:0.33-3.38], $p=0,9228)$ and its treatment did not modify early-PJI incidence (OR:1.03[95\%Cl:0.15-7.10], $p=0.9787$ ).

Conclusions: Neither preoperative ASB nor its treatment were risk factors of early-PJI after HHA.

Trial Registration: Eudra CT 2016-001108-47

\section{Introduction}

Early-periprosthetic joint infection (early-PJI) after joint replacement is a challenging complication. Rates of early-PJI are higher in HHA patients than in total hip arthroplasty (THA) and range between 1.3-9\%[15].

Bacterial colonization of the genitourinary tract as an infection cause of hip prostheses during a haematogenous seeding or due to contamination of the skin by continuity has been suggested. This asymptomatic colonization is called asymptomatic bacteriuria (ASB) and its prevalence reaches $30-50 \%$ in elderly women in long-term care facilities [6]. Published studies demonstrated that preoperative ASB treatment among candidates for elective total hip and knee arthroplasties has no impact in early-PJI [711]. However, its impact on patients undergoing HHA is a matter of controversy with a single-center study concluding that treating ASB in geriatric patients with a femur fracture decreases the risk of PJIs [12].

We evaluate the impact of preoperative ASB treatment in the cumulative incidence of early-PJI in patients undergoing HHA for a hip fracture. We hypothesized that preoperative ASB treatment in these patients could decrease the incidence of early-PJI caused by Gram-negative bacilli (GNB).

\section{Patients And Methods}

BARIFER was a phase IV, multicentre, randomized, open-label and parallel-group clinical trial conducted at 11 sites in Spain designed to evaluate the impact of treating ASB on the incidence of early-PJI in HHA.

All patients provided informed consent. Protocol approval was obtained from an independent ethics committee at each site. The trial (EudraCT 2016-001108-47) was performed under the principles of the 
Declaration of Helsinki. Adherence to the Consolidated Standards of Reporting Trials [13] (CONSORT) is supported by the completed checklist provided as Supplementary material.

Patients $\geq 18$ years requiring HHA for fracture were recruited. Exclusion criteria include any concomitant infection requiring antibiotics and hip fractures treated with screws or THA.

Urine analysis was performed before HHA surgery. ASB referred to a urine culture growing $\geq 10^{5}$ colonyforming units $/ \mathrm{mL}$ of a bacterial species in a patient lacking symptoms of a urinary tract infection (UTI). All microorganisms isolated were identified by standard procedures. Antimicrobial susceptibility was performed by microdilution (Vitek bioMérieux, France). The MIC values of fosfomycin were interpreted according to EUCAST criteria 2012 (version 2.0) guidelines (www.eucast.org).

Participants with ASB were randomly assigned in a 1:1 ratio, centralized and stratified by centre, to receive $3 \mathrm{~g}$ of fosfomycin-trometamol (oral route) vs. no treatment, between 24 and $6 \mathrm{~h}$ before surgery. A parallel follow-up cohort of HHA candidates without ASB was established.

Preoperative antibiotic prophylaxis was decided according to each centre protocol (Supplementary Table 1). All patients were followed for 3 months after HHA or until early-PJls or death was diagnosed, whichever occurred first.

PJIs occurring within 3 months after HHA were considered early-PJIs [14]. Patients were diagnosed with a PJI following diagnostic criteria established by the Infectious Diseases Society of America [15]. In case of early-PJI, a new visit was completed in which the microorganism causing the infection was recorded.

Primary outcome: cumulative incidence of early-PJI after preoperative ASB treatment. Secondary analyses included global incidence of ASB and early-PJI, risk factors for early-PJI and safety of fosfomycin treatment.

\section{Statistical Analysis}

Categorical variables were presented as number and percentages and quantitative variables as a median and interquartile range or a mean and standard deviation, as appropriate. Comparative analyses were performed using $X^{2}$ or Fisher's test for categorical variables, and Student's t-test or Mann-Whitney U-test for continuous variables. Level of significance was set to $p<0.05$. Predictors of early-PJI were determined by univariate analysis. The Kaplan-Meier method was used to describe cumulative probability early-PJI stratified by study group.

The EAST program calculated the sample size. We assumed a prevalence of ASB up to $20 \%$ in men and $50 \%$ in women, an incidence of $9 \%$ of early-PJI and an expected $50 \%$ reduction with fosfomycin treatment with a test power of $90 \%$ and alpha error of 0.05 . We needed 1394 patients (697 in each treatment group). An interim analysis was planned to stop the study in case it would not be possible to test the hypothesis. Analyses were performed with STATA 15.1 software (StataCorp, TX, USA) in the intention-to-treat (ITT) population. 


\section{Results}

A total of 594 patients were included from September 2016 to November 2018. Overall, $420(71.0 \%)$ were women and the mean age was 84.3 years. ASB was diagnosed in 152(25\%) patients, 77 treated with Fosfomycin and 75 untreated controls. Figure 1 shows the flow chart of patients' distribution.

Patients with ASB versus the non-ASB group were mostly women, with a higher Charlson comorbidity index score and more commonly with urinary incontinence (Table 1). Supplementary table 2 shows causative isolates of ASB. As expected, $82 \%$ were GNBs (Mostly Escherichia coli and Klebsiella spp.) of which $89 \%$ were susceptible to fosfomycin. Table 2 compares baseline characteristics of treated and untreated patients with ASB.

HHA implants were $65.46 \%$ cemented with antibiotics (64\% with single-antibiotic and $36 \%$ with dualantibiotic Vancogen $\left.{ }^{\circledR}\right)$.

Overall, 558(93.9\%) patients (140 with ASB and 418 without) completed 3 months of follow-up (Table 3 ). Early-PJI rate was $2.5 \%$ ( 15 of 594 patients). Of these 15 patients, 4(2.7\%) showed previous ASB but only 2 were treated with fosfomycin (Table 3). Our trial showed that treating preoperative ASB does not modify the incidence of early-PJI (OR: 1.03 [95\% Cl: 0.15-7.10], $p=0.9787)$. Of note, all early-PJI occurred within 60 days after HHA (Figure 2). Table 4 shows the aetiology of the 15 early-PJls. We observed a lack of correspondence between ASB and early-PJI causing microorganisms. Univariate analysis of risk factors for early-PJI is presented in Table 5. Preoperative ASB was not a predictor of early-PJI (OR: 1.06 [95\%Cl: 0.33-3.38], $p=0.9228$ ).

AEs related to Fosfomycin occurred in 4 patients, all of them of mild intensity. Three patients suffered from nausea and one reported dizziness (Supplementary Table 3).

\section{Discussion}

Identifying potentially modifiable preoperative risk factors of PJIs is of great interest. Experts traditionally recommended treating ASB before THA [16-19] although the latest published studies contradict this recommendation $[7,8,10,11]$. There are only two previous randomized controlled trials addressing this subject including both THA and HHA $[7,8]$. Our findings suggest that preoperative ASB treatment does not have an impact on the reduction of early-PJI after HHA. Ours is the first randomized trial which only enrolled this subgroup of patients.

The prevalence of ASB in our cohort was $25 \%$ which is higher than in THA candidates $[7,8,16]$ and consistent with data reported for HHA [20]. Female sex, adjusted Charlson index and urinary incontinence are significantly more prevalent in the ASB group as previously reported [7].

Almost $90 \%$ of the identified GNB causing ASB were susceptible to fosfomycin as previously published $[21,22]$. The efficacy of a single dose of fosfomycin-trometamol for uncomplicated lower UTI is 
comparable with standard regimens with fluoroquinolones or trimethoprim/sulfamethoxazole [23] and easier to administer, therefore, it was chosen as preoperative treatment. Fosfomycin has a low incidence of AEs which mainly comprise mild and transient gastrointestinal symptoms [23]. This matches our study as only 4 patients experienced some associated nausea or dizziness.

Only 4 patients with ASB had an early-PJI which represents an incidence of $2.7 \%$. Although this is lower than expected $[4,7,8]$, it is consistent with the latest data collected in the VINCat registry (surveillance database of nosocomial infections in Catalonia) [5]. When investigating risk factors for early-PJI our study focuses on preoperative ASB. In our series ASB is not a risk factor for early-PJI unlike other published data showing that, although the risk of PJI is not influenced by ASB treatment, there seems to be an increased risk of PJI in this population [7]. It is also remarkable that in no case the microorganism causing ASB was identical as the one causing early-PJI which has also been highlighted by other authors $[7,24]$. In our experience ASB treatment does not modify the incidence of early-PJI. Although we observed a delay from HHA surgery to onset of infection of about 10 days higher in patients treated with Fosfomycin, the exceptionally low number of events prevents us from reaching any conclusion. Therefore, since we have not been able to demonstrate a potential benefit in treating preoperative ASB we do not recommend systematic urinalysis screening and treatment.

Also noteworthy is the percentage of antibiotic-loaded cement used. Published studies show that it leads to a reduction in the rate of PJIs in HHA with no associated increase in complications [25-27]. This approach could justify a global reduction of early-PJ rates compared to our previous incidence between 2011 and 2013 [4].

Finally, global mortality in our series is high ( $9 \%$ of our patients) but it could be explained by the age and comorbidity of the population, particularly among those with ASB, as evidenced by the high Charlson comorbidity index values $[1,28]$.

The main limitation of our study is the small sample size. The difficulty of obtaining informed consent signature in time to complete the entire inclusion process at least 6 hours before surgery made our inclusion rate slow. We did an interim analysis that showed that it would not be possible to test the hypothesis and for this reason we decided to end the study. It is also possible that we overestimate the incidence of early-PJI after HHA and therefore the study might be underpowered to confirm the hypothesis. The main strengths of the study are its design (randomized trial) and having included geriatric patients (frequently underrepresented in clinical trials) all of them undergoing HHA.

In conclusion, our results suggest that ASB is not an independent risk factor for early-PJ and its treatment did not reduce the incidence of early-PJI after HHA. Therefore, we cannot recommend routine screening and treatment of preoperative ASB in HHA surgery.

Part of this study was presented at the XXIII Congreso Nacional de la Sociedad Española de Enfermedades Infecciosas y Microbiología Clínica, which took place in Madrid, on 23-25th May 2019. 


\section{Declarations}

\section{Supplementary Data}

Supplementary materials are available online.

\section{Notes}

\section{Acknowledgments}

We thank Maria Romero (Trialance, S.L.) for medical writing support, Santiago Perez Hoyos (Unitat d'Estadística i Bioinformàtica (UEB)) for the statistical calculations and Mercedes Vila for her assistance in the methodology and implementation of the project.

\section{Funding}

This work was supported by the Spanish Clinical Research Network (SCReN), co-finaced by the ISCIIISubdirección General de Evaluación y Fomento de la Investigación, through the project PI15/02161 and by the Plan Nacional de I+D+i 2013-016 and ISCIIII, Subdireccion General de Redes y Centros de Investigacion Cooperativa, Ministerio de Economia, Industria y Competitividad, Spanish Network for Research in Infectious Diseases (REIPI RD16/0016/0003)-co-financed by European Development Regional Fund "A way to achieve Europe", Operative program Intelligent Growth 2014-2020.

\section{Transparency declaration}

The authors declare that they have no conflict of interest.

\section{Author's contributions}

Dr Rodriguez-Pardo and Dr Pigrau contributed to its Conception, Clinical trial design, Protocol, Data collection, Patient recruitment, Data analysis and writing the paper with the assistance of a medical writer. Dr Corona and Dr Almirante contributed to its Conception, Clinical trial design and Reviewing and editing the manuscript. All the other authors participated in Patient recruitment, Data collection, Reviewing and editing the manuscript. All authors approved the submitted versions, had full access to the data (under confidentiality agreements), and vouch for the accuracy and completeness of the data and for the fidelity of the trial to the protocol.

\section{LIST OF COLLABORATORS/GROUP OF INVESTIGATORS FOR BARIFER CLINICAL TRIAL}

This is a multicentre study. In each institution there are many researchers that have helped to make this study possible. We are deeply indebted to these collaborators, who are:

Jaume Mestre and Maria del Mar Villar (Internal Medicine Department, Hospital Universitari Vall d'Hebron, Universitat Autònoma de Barcelona, Barcelona, Spain) 
Álvaro Corrales Díaz and Myriam Rodríguez Rodríguez (Orthopedic Surgery Department Hospital Universitario Virgen Macarena, Seville, Spain)

Nerea Hernández González and Lorena Díez López (Orthopedic Surgery Department, Hospital Universitario Cruces, Vizcaya, Spain)

Javier Cobo (Infectious Diseases Department, Hospital Universitario Ramón y Cajal, Madrid, Spain) and Isabel Perez Millán (Geriatrics Department, Hospital Ramón y Cajal, Madrid, Spain).

$M^{a}$ Isabel Perez Núñez (Orthopedic Surgery Department, Hospital Universitario Marqués de Valdecilla, Santander, Spain), M Carmen Fariñas Alvarez (Infectious Diseases Department, Hospital Universitario Marqués de Valdecilla, Santander, Spain), Hospital and Zoilo Yusta Escudero (Geriatrics Department, Hospital Universitario Marqués de Valdecilla, Santander, Spain),

Elena Muñez Rubio, Isabel Sánchez Romero (Hospital Universitario Puerta de Hierro, Majadahonda, Spain).

Cristina Dauder Gallego (Orthopedic Surgery Department, Hospital Universitario Fundación Alcorcón. Madrid, Spain), Oriol Martin Segarra (Internal Medicine Department, Infectious Diseases Division, Hospital Universitario Fundación Alcorcón. Madrid, Spain), Jesús Ignacio Collado Álvarez and Ma Mar Bermejo Olano (Internal Medicine Department Hospital Universitario Fundación Alcorcón. Madrid, Spain).

Oscar Murillo (Infectious Diseases Department, Hospital Universitari de Bellvitge, Barcelona, Spain), Salvador Pedrero (Orthopedic Surgery Department Hospital Universitari de Bellvitge, Barcelona, Spain).

Melcior Riera (Internal Medicine Department, Hospital Universitario Son Espasses, Palma de Mallorca, Spain).

María Gomáriz Díaz (Microbiology Department. Hospital Universitario Donostia), Gaspar De la Herrán (Orthopedic Surgery Department. Hospital Universitario Donostia), H. Azkune (Infectious Diseases Department Hospital Universitario Donostia, San Sebastián, Spain).

Marta Almenara Fernández, Eduard Ramírez Bermejo, Judit Martínez Zaragoza, (Infectious Diseses Department, Hospital Santa Creu i Sant Pau, Barcelona, Spain) Ferran Navarro Risueño (Microbiology Department, Hospital Santa Creu i Sant Pau, Barcelona, Spain)

\section{References}

1. Edwards C, Counsell A, Boulton C, Moran CG. Early infection after hip fracture surgery. J. Bone Jt. Surg. - Ser. B 2008;90:770-7. doi: 10.1302/0301-620X.90B6.20194

2. Cordero-Ampuero J, De Dios M. What are the risk factors for infection in hemiarthroplasties and total hip arthroplasties? Clin. Orthop. Relat. Res. 2010;468:3268-77. doi: 10.1007/s11999-010-1411-8 
3. Phillips JRA, Moran CG, Manktelow ARJ. Periprosthetic fractures around hip hemiarthroplasty performed for hip fracture. Injury 2013;44:757-62. doi: 10.1016/j.injury.2012.09.015

4. Gallardo-Calero I, Larrainzar-Coghen T, Rodriguez-Pardo D, Pigrau C, Sánchez-Raya J, Amat C, et al. Increased infection risk after hip hemiarthroplasty in institutionalized patients with proximal femur fracture. Injury 2016;47. doi: 10.1016/j.injury.2015.12.032

5. Vigilància de la infecció nosocomial als hospitals de Catalunya (VINCat), informe 2017 [Internet]. doi: https://catsalut.gencat.cat/web/.content/minisite/vincat/documents/informes/informe2017.pdf

6. Nicolle LE, Gupta K, Bradley SF, Colgan R, DeMuri GP, Drekonja D, et al. Clinical Practice Guideline for the Management of Asymptomatic Bacteriuria: 2019 Update by the Infectious Diseases Society of Americaa. Clin. Infect. Dis. 2019;68:1611-5. doi: 10.1093/cid/ciz021

7. Sousa R, Muñoz-Mahamud E, Quayle J, Da Costa LD, Casals $C$, Scott $P$, et al. Is asymptomatic bacteriuria a risk factor for prosthetic joint infection? Clin. Infect. Dis. 2014;59:41-7. doi:

$10.1093 / \mathrm{cid} / \mathrm{ciu} 235$

8. Cordero-Ampuero J, González-Fernández E, Martínez-Vélez D, Esteban J. Are antibiotics necessary in hip arthroplasty with asymptomatic bacteriuria? Seeding risk with/without treatment. Clin. Orthop. Relat. Res. 2013;471:3822-9. doi: 10.1007/s11999-013-2868-z

9. Drekonja DM, Zarmbinski B, Johnson JR. Preoperative Urine Cultures at a Veterans Affairs Medical Center. JAMA Intern. Med. 2013;173:71. doi: 10.1001/2013.jamainternmed.834

10. Bouvet $C$, Lübbeke A, Bandi C, Pagani L, Stern R, Hoffmeyer P, et al. Is there any benefit in preoperative urinary analysis before elective total joint replacement? Bone Joint J. [Internet] 2014 [cited 2021 14];96-B:390-4. doi: https://pubmed.ncbi.nlm.nih.gov/24589797/doi: 10.1302/0301$620 x .96 \mathrm{~b} 3.32620$

11. Mayne AIW, Davies PSE, Simpson JM. Antibiotic treatment of asymptomatic bacteriuria prior to hip and knee arthroplasty; a systematic review of the literature [Internet]. Surgeon 20181 [cited 2021 14];16:176-82. doi: https://pubmed.ncbi.nlm.nih.gov/29174023/doi: 10.1016/j.surge.2017.08.007

12. Langenhan R, Bushuven $S$, Reimers N, Probst A. Peri-operative antibiotic treatment of bacteriuria reduces early deep surgical site infections in geriatric patients with proximal femur fracture. Int. Orthop. [Internet] 20181 [cited 2021 14];42:741-6. doi: https://pubmed.ncbi.nlm.nih.gov/29224055/doi: 10.1007/s00264-017-3708-7

13. Moher D, Schulz KF, Altman DG, Lepage L. The CONSORT statement: Revised recommendations for improving the quality of reports of parallel-group randomized trials. Ann. Intern. Med. 2001;134:65762. doi: 10.7326/0003-4819-134-8-200104170-00011

14. Zimmerli W, Trampuz A, Ochsner PE. Current concepts: Prosthetic-joint infections. N. Engl. J. Med. 2004;351:1645-54. doi: 10.1056/NEJMra040181

15. Osmon DR, Berbari EF, Berendt AR, Lew D, Zimmerli W, Steckelberg JM, et al. Diagnosis and management of prosthetic joint infection: clinical practice guidelines by the Infectious Diseases Society of America. Clin. Infect. Dis. 2013;56:e1-25. doi: 10.1093/cid/cis803 
16. Glynn MK SJ. The significance of asymptomatic bacteriuria in patients undergoing hip/knee arthroplasty. - PubMed - NCBI [Internet]. Clin Orthop Relat Res. 1984 [cited 2020 6];(185):151-4. doi: https://www.ncbi.nlm.nih.gov/pubmed/6705373

17. David TS, Vrahas MS. Perioperative lower urinary tract infections and deep sepsis in patients undergoing total joint arthroplasty. J. Am. Acad. Orthop. Surg. 2000;8:66-74. doi: 10.5435/00124635-200001000-00007

18. Rajamanickam A, Noor S, Usmani A. Should an asymptomatic patient with an abnormal urinalysis (bacteriuria or pyuria) be treated with antibiotics prior to major joint replacement surgery? Cleve. Clin. J. Med. 2007;74:17-8. doi: 10.3949/ccjm.74.Electronic_Suppl_1.S17

19. Otermin I, Rivero M, Hidalgo Á. Es necesario retrasar o suspender la cirugía en el caso de una posible bacteriuria asintomática? ¿y una cirugía con implantes en ortopedia? Enferm. Infecc. Microbiol. Clin. 2009;27:252-3. doi: 10.1016/j.eimc.2008.03.005

20. Nicolle L. Symptomatic urinary tract infection or asymptomatic bacteriuria? Improving care for the elderly. Clin. Microbiol. Infect. [Internet] 2019;25:779-81. doi:

https://doi.org/10.1016/j.cmi.2019.03.013doi: 10.1016/j.cmi.2019.03.013

21. Bosch-Nicolau P, Falcó V, Viñado B, Andreu A, Len O, Almirante B, et al. A cohort study of risk factors that influence empirical treatment of patients with acute pyelonephritis. Antimicrob. Agents Chemother. 2017;61:1-11. doi: 10.1128/AAC.01317-17

22. Falagas ME, Kastoris AC, Kapaskelis AM, Karageorgopoulos DE. Fosfomycin for the treatment of multidrug-resistant, including extended-spectrum $\beta$-lactamase producing, Enterobacteriaceae infections: a systematic review. Lancet Infect. Dis. 2010;10:43-50. doi: 10.1016/S14733099(09)70325-1

23. Patel SS, Balfour JA, Bryson HM. Fosfomycin Tromethamine. A review of its antibacterial activity, pharmacokinetic properties and therapeutic efficacy as a single-dose oral treatment for acute uncomplicated lower urinary tract infections. Drugs 1997;53:637-56. doi: 10.2165/00003495199753040-00007

24. Sousa RJG, Abreu MA, Wouthuyzen-Bakker M, Soriano A V. Is Routine Urinary Screening Indicated Prior To Elective Total Joint Arthroplasty? A Systematic Review and Meta-Analysis. J. Arthroplasty [Internet] 2019;34:1523-30. doi: https://doi.org/10.1016/j.arth.2019.03.034doi: 10.1016/j.arth.2019.03.034

25. Sprowson AP, Jensen C, Chambers S, Parsons NR, Aradhyula NM, Carluke I, et al. The use of highdose dual-impregnated antibiotic-laden cement with hemiarthroplasty for the treatment of a fracture of the hip the fractured hip infection trial. Bone Jt. J. 2016;98-B:1534-41. doi: 10.1302/0301620X.98B11.34693

26. Jameson SS, Jensen CD, Elson DW et al. Cemented versus cementless hemiar- throplasty for intracapsular neck of femur fracture--a comparison of 60,848 matched patients using national data. Injury 2013;44:730-4. 
27. Middleton RG, Uzoigwe CE, Young PS et al. Peri-operative mortality after hemi- arthroplasty for fracture of the hip: does cement make a difference? Bone Jt. J 2014;96-B:1185-1191.

28. Barbero JM, Montero E, Vallés A, Plasencia MA, Romanyk J, Gómez J. Prosthetic joint infection in patients with hip fracture. Differences from infection of elective prosthesis. Rev. Esp. Quimioter. 2016;29:273-7.

\section{Tables}

Table 1. Baseline demographics and clinical characteristics of patients (ITT analysis) 


\begin{tabular}{|c|c|c|c|c|c|}
\hline Characteristics & $\begin{array}{l}\text { Patients with } \\
\text { ASB } \\
(n=152 \\
100 \%)\end{array}$ & $\begin{array}{l}\text { Patients } \\
\text { without ASB } \\
(n=442,100 \%)\end{array}$ & $\begin{array}{l}\text { Total } \\
(n= \\
594,100 \%)\end{array}$ & P Value & OR (95\% Cl) \\
\hline Age, mean (SD) & $84.5(7.9)$ & $84.2(8.5)$ & $84.3(8.34)$ & \multirow[t]{2}{*}{0.7725} & \multirow{2}{*}{$\begin{array}{l}1.003 \\
\text { (0.981; } \\
1.026)\end{array}$} \\
\hline Median (Q1-Q3), y & $\begin{array}{l}86.0(81.7 ; \\
89.6)\end{array}$ & $86.0(80.6 ; 89.7)$ & $\begin{array}{l}86.0(80.7 ; \\
89.7)\end{array}$ & & \\
\hline Female sex & $124(81.6 \%)$ & $296(67.0 \%)$ & $420(70.7 \%)$ & 0.0008 & $\begin{array}{l}2.18(1.39 \\
3.44)\end{array}$ \\
\hline \multicolumn{6}{|l|}{ Comorbid conditions } \\
\hline BMI mean (SD) & $24.4(4.5)$ & $24.3(3.5)$ & $24.4(3.8)$ & \multirow[t]{2}{*}{0.8319} & \multirow{2}{*}{$\begin{array}{l}1.01(0.95 \\
1.07)\end{array}$} \\
\hline $\begin{array}{l}\text { Median (Q1-Q3), } \\
\mathrm{kg} / \mathrm{m} 2\end{array}$ & $\begin{array}{l}24.8 \\
(21.5 ; 26.6)\end{array}$ & $24.2(21.6 ; 26.6)$ & $\begin{array}{l}24.2 \\
(21.6 ; 26.6)\end{array}$ & & \\
\hline $\begin{array}{l}\text { Obesity (BMI } \geq 30 \\
\mathrm{~kg} / \mathrm{m} 2)\end{array}$ & $9(8.3 \%)$ & $14(5.3 \%)$ & $23(6.2 \%)$ & 0.2886 & $\begin{array}{l}1.46(0.73 \\
2.95)\end{array}$ \\
\hline Cardiac failure & $19(12.6 \%)$ & $45(10.2 \%)$ & $64(10.8 \%)$ & 0.4124 & $\begin{array}{l}1.27(0.72 \\
2.25)\end{array}$ \\
\hline $\begin{array}{l}\text { Peripheral } \\
\text { vasculopathy }\end{array}$ & $15(9.9 \%)$ & $41(9.3 \%)$ & $56(9.4 \%)$ & 0.8114 & $\begin{array}{l}1.27(0.58 \\
2.01)\end{array}$ \\
\hline Diabetes & $45(29.8 \%)$ & $106(24.0 \%)$ & $151(25.4 \%)$ & 0.1573 & $\begin{array}{l}1.35(0.89 \\
2.03)\end{array}$ \\
\hline Dementia & $50(33.1 \%)$ & $118(26.7 \%)$ & $168(28.3 \%)$ & 0.1317 & $\begin{array}{l}1.36(0.91 ; \\
2.03)\end{array}$ \\
\hline Chronic bronchopathy & 19 (12.6\%) & $49(11.1 \%)$ & $68(11.5 \%)$ & 0.6184 & $\begin{array}{l}1.15(0.66 \\
2.03)\end{array}$ \\
\hline Cirrhosis & $6(3.97 \%)$ & $6(1.4 \%)$ & $12(2.0 \%)$ & 0.0600 & $\begin{array}{l}3.01(0.95 \\
9.47)\end{array}$ \\
\hline Chronic renal failure & $28(18.4 \%)$ & $67(15.1 \%)$ & $95(16.0 \%)$ & 0.3446 & $\begin{array}{l}1.26 \\
2.05)\end{array}$ \\
\hline \multicolumn{6}{|l|}{ Charlson index score* } \\
\hline mean (SD) & $6.1(2.2)$ & $5.6(1.9)$ & $5.8(2.0)$ & \multirow[t]{2}{*}{0.0146} & \multirow{2}{*}{$\begin{array}{l}1.12(1.02 ; \\
1.22)\end{array}$} \\
\hline median (Q1-Q3) & $6.0(5.0 ; 7.0$ & $5.0(4.0 ; 7.0)$ & $\begin{array}{l}6.0(4.0 ; \\
7.0)\end{array}$ & & \\
\hline Urinary incontinence & $52(34.4 \%)$ & $78(17.7 \%)$ & $130(22.0 \%)$ & $<0.0001$ & $\begin{array}{l}2.44(1.61 ; \\
3.70)\end{array}$ \\
\hline Rheumatoid arthritis & $1(0.7 \%)$ & $8(1.8 \%)$ & $9(1.5 \%)$ & 0.3395 & $\begin{array}{l}0.36 \\
(0,04 ; 2.92)\end{array}$ \\
\hline Immunosuppressors** & $7(4.6 \%)$ & $25(5.6 \%)$ & $32(5.4 \%)$ & 0.6121 & 0.81 \\
\hline
\end{tabular}


$(0.34 ; 1.90)$

\begin{tabular}{|c|c|c|c|c|c|}
\hline Malignancy & $11(7.2 \%)$ & $32(7.2 \%)$ & $43(7.2 \%)$ & 0.9990 & $\begin{array}{l}1.00(0.491 ; \\
2.04)\end{array}$ \\
\hline $\begin{array}{l}\text { Anticoagulant } \\
\text { treatment }\end{array}$ & $40(26.5 \%)$ & 101 (22.8\%) & $141(23.8 \%)$ & 0.3649 & $\begin{array}{l}1.22(0.80 ; \\
1.86)\end{array}$ \\
\hline Antiplatelet treatment & $44(29.1 \%)$ & $130(29.4 \%)$ & $174(29.3 \%)$ & 0.9493 & $\begin{array}{l}0.36(0.04 ; \\
2.92)\end{array}$ \\
\hline
\end{tabular}

Unless otherwise specified, data represent No. (\%) of patients.

Abbreviations: ITT, intention to treat analysis; ASB, asymptomatic bacteriuria; OR, odds ratio; $\mathrm{Cl}$, confidence interval; SD, Standard Deviation; BMI, body mass index

${ }^{*}$ Charlson index score is adjusted by age

** Immunosuppressors includes steroids, classic immunosuppressors (ie: methotrexate, azathioprine, mycophenolate), biological drugs and chemotherapy

Table 2. Baseline characteristics of Treated and Untreated Patients with ASB. 


\begin{tabular}{|c|c|c|c|}
\hline \multicolumn{4}{|c|}{ Patients, No. (\%) } \\
\hline Characteristic & $\begin{array}{l}\text { Untreated } \\
\text { ASB }\end{array}$ & $\begin{array}{l}\text { ASB treated with } \\
\text { Fosfomycin }\end{array}$ & Total \\
\hline & $(\mathrm{N}=75,100 \%)$ & $(\mathrm{N}=77,100 \%)$ & $\begin{array}{l}(N=152, \\
100 \%)\end{array}$ \\
\hline Age, mean (SD), y & $84.2(8.6)$ & $84.6(7.2)$ & $84.5(7.9)$ \\
\hline Median (Q1-Q3), y & $\begin{array}{l}85.9 \\
(81.6 ; 89.9)\end{array}$ & $86.15(81.7 ; 89.4)$ & $\begin{array}{l}85.96 \\
(81.7 ; 89.6)\end{array}$ \\
\hline Female sex & $59(78.7 \%)$ & $65(84.4 \%)$ & $124(81.6 \%)$ \\
\hline \multicolumn{4}{|l|}{ Comorbid conditions } \\
\hline $\mathrm{BMI}^{\mathrm{a}}$ mean $(\mathrm{SD}), \mathrm{y}$ & $24.6(4.7)$ & $24.2(4.1)$ & $24.4(4.46)$ \\
\hline Median (Q1-Q3), y & $\begin{array}{l}24.9 \\
(21.6 ; 26.7)\end{array}$ & $23.5(21.5 ; 26.6)$ & $\begin{array}{l}24.8 \\
(21.5 ; 26.6)\end{array}$ \\
\hline Cardiac failure & $11(14.9 \%)$ & $8(10.4 \%)$ & $19(12.6 \%)$ \\
\hline Peripheral vasculopathy & $8(10.8 \%)$ & $7(9.1 \%)$ & $15(9.9 \%)$ \\
\hline Cerebral vasculopathy & $14(18.9 \%)$ & $13(16.9 \%)$ & $27(17.9 \%)$ \\
\hline Dementia & $22(29.7 \%)$ & $28(36.4 \%)$ & $50(33.1 \%)$ \\
\hline Chronic Bronchopathy & $12(16.2 \%)$ & $7(9.1 \%)$ & $19(12.6 \%)$ \\
\hline Cirrhosis & $3(4.0 \%)$ & $3(3.1 \%)$ & $6(4.0 \%)$ \\
\hline Diabetes & $24(32.4 \%)$ & $21(27.3 \%)$ & $45(29.8 \%)$ \\
\hline Chronic renal failure & $14(18.7 \%)$ & $14(18.2 \%)$ & $28(18.4 \%)$ \\
\hline Malignancy & $6(8.7 \%)$ & $5(6.5 \%)$ & $11(7.3 \%)$ \\
\hline Immunosuppressors** & $7(9.3 \%)$ & $1(1.3 \%)$ & $8(5.3 \%)$ \\
\hline Anticoagulant treatment & $20(27.0 \%)$ & $20(26.0 \%)$ & $40(26.5 \%)$ \\
\hline Antiplatelet treatment & $23(31.1 \%)$ & $21(27.3 \%)$ & $44(29.1 \%)$ \\
\hline Rheumatoid arthritis & $1(1.3 \%)$ & $0(0 \%)$ & $1(0.7 \%)$ \\
\hline Urinary incontinence & $27(36.5 \%)$ & $25(32.5 \%)$ & $52(34.4 \%)$ \\
\hline \multicolumn{4}{|l|}{ Charlson index score* } \\
\hline mean $(S D)$ & $6.19(2.3)$ & $6.0(2.2)$ & $6.1(2.2)$ \\
\hline median (Q1-Q3) & $6.0(5.0 ; 8.0)$ & $6.0(4.0 ; 7.0)$ & $6.0(5.0 ; 7.0)$ \\
\hline \multicolumn{4}{|c|}{ Days from admission to $\mathrm{HHA}^{*}$} \\
\hline mean (SD) & $4.3(6.9)$ & $3.7(2.2)$ & $4.0(5.1)$ \\
\hline
\end{tabular}




\begin{tabular}{|llll|}
\hline \multicolumn{1}{|c}{ median (Q1-Q3) } & $3.0(2.0 ; 5.0)$ & $3.0(2.0 ; 5.0)$ & $3.0(2.0 ; 5.0)$ \\
\hline $\begin{array}{l}\text { Duration of HHA surgery } \\
\text { mean (SD), min }\end{array}$ & $94.9(27.2)$ & $93.26(23.4)$ & $94.1(25.4)$ \\
median (Q1-Q3), min & $\begin{array}{l}90.0 \\
(75.0 ; 120.0)\end{array}$ & $90.0(80.0 ; 5.0)$ & 90.0 \\
\hline Duration of HHA surgery & $17(28.3 \%)$ & $12(21.0 \%)$ & $29(24.8 \%)$ \\
$>75^{\text {th }}$ percentile & & & $133(89.3 \%)$ \\
\hline Antibiotic Cemented HHA & $67(89.3 \%)$ & $66(89.2 \%)$ & $85(26 \%)$ \\
\hline HHA dislocation & $4(5.3 \%)$ & $4(5.2 \%)$ & $13(8.5 \%)$ \\
\hline Postoperative UTI & $6(8 \%)$ & $7(9.1 \%)$ & $7(4.6 \%)$ \\
\hline Postoperative infection other than UTI & $4(5.3 \%)$ & $3(3.9 \%)$ & $53(37.9 \%)$ \\
\hline $\begin{array}{l}\text { Patients transferred to a } \\
\text { convalescence centre }\end{array}$ & $28(40 \%)$ & $35(50 \%)$ & \\
\hline
\end{tabular}

Unless otherwise specified, data represent No. (\%) of patients.

Abbreviations: ASB, asymptomatic bacteriuria; BMI, body mass index; ASA, American society of anesthesiologists; HHA, hip hemiarthroplasty; UTI, urinary tract infection; PJI, periprosthetic joint infection.

${ }^{a}$ Data available for 109 patients (58 untreated ASB and 51 treated ASB)

* Charlson index score is adjusted by age.

** Immunosuppressors includes steroids, classic immunosuppressors (ie: methotrexate, azathioprine, mycophenolate), biological drugs and chemotherapy

Table 3. Overall outcomes (ITT analysis) 


\begin{tabular}{|c|c|c|c|c|}
\hline \multirow[t]{3}{*}{ Outcome } & \multicolumn{2}{|l|}{ ASB Patients } & \multirow{3}{*}{$\begin{array}{l}\text { Non-ASB } \\
\text { Patients } \\
\\
442 \\
(100 \%)\end{array}$} & \multirow{3}{*}{$\begin{array}{l}\text { Total } \\
\\
594 \\
(100 \%)\end{array}$} \\
\hline & $\begin{array}{l}\text { Not treated with } \\
\text { Fosfomycin }\end{array}$ & $\begin{array}{l}\text { Treated with } \\
\text { Fosfomycin }\end{array}$ & & \\
\hline & $75(100 \%)$ & $77(100 \%)$ & & \\
\hline No HHA infection after 12 weeks & $59(78.7 \%)$ & $56(72.7 \%)$ & $\begin{array}{l}369 \\
(83.5 \%)\end{array}$ & $\begin{array}{c}484 \\
(81.7 \%)\end{array}$ \\
\hline Death within 12 weeks & $9(12 \%)$ & $11(14.3 \%)$ & $34(7.7 \%)$ & $54(9 \%)$ \\
\hline Early-PJI & $2(2.7 \%)$ & $2(2.6 \%)$ & $11(2.5 \%)$ & $\begin{array}{c}15 \\
(2.5 \%)\end{array}$ \\
\hline Loss of follow-up & $4(5.3 \%)$ & $8(10.4 \%)$ & $25(5.6 \%)$ & $36(6.1)$ \\
\hline $\begin{array}{l}\text { Prostheses removed due to } \\
\text { orthopaedic reasons }\end{array}$ & $1(1.3 \%)$ & $0(0 \%)$ & $3(0.7 \%)$ & $\begin{array}{c}4 \\
(0.7 \%)\end{array}$ \\
\hline
\end{tabular}

Abbreviations: ITT, Intention to treat; ASB, Asymptomatic bacteriuria; HHA, Hip hemiarthroplasty; PJI, periprosthetic joint infection

Table 4. Aetiology, relationship with ASB and outcome of early-PJI infections 


\begin{tabular}{|c|c|c|c|c|c|}
\hline \multirow[t]{2}{*}{ Patients } & \multirow{2}{*}{$\begin{array}{l}\text { Patients } \\
\text { without ASB }\end{array}$} & \multicolumn{2}{|c|}{ Patients with ASB } & \multirow{2}{*}{$\begin{array}{l}\text { Aetiology of } \\
\text { early-PJl }\end{array}$} & \multirow{2}{*}{$\begin{array}{l}\text { Aetiology of } \\
\text { ASB }\end{array}$} \\
\hline & & $\begin{array}{l}\text { Treated with } \\
\text { Fosfomycin }\end{array}$ & $\begin{array}{l}\text { Not treated with } \\
\text { Fosfomycin }\end{array}$ & & \\
\hline 1 & $x$ & & & MSSA & \\
\hline 2 & & $x$ & & S. epidermidis & E. coli \\
\hline 3 & $x$ & & & MSSA & \\
\hline 4 & & & $x$ & C. striatum & $\begin{array}{l}\text { K. } \\
\text { pneumoniae }\end{array}$ \\
\hline 5 & $\mathrm{x}$ & & & $\begin{array}{l}\text { E. coli ESBL } \\
\text { producer }\end{array}$ & \\
\hline 6 & $x$ & & & $\begin{array}{l}\text { E. coli ESBL } \\
\text { producer }\end{array}$ & \\
\hline 7 & $x$ & & & MRSA. & \\
\hline 8 & $x$ & & & $\begin{array}{l}\text { K. } \\
\text { pneumoniae }\end{array}$ & \\
\hline 9 & & $x$ & & $M R S A$ & $\begin{array}{l}\text { E. coli ESBL } \\
\text { producer }\end{array}$ \\
\hline 10 & $x$ & & & $\begin{array}{l}\text { E. coli ESBL } \\
\text { producer* }\end{array}$ & \\
\hline 11 & $\mathrm{x}$ & & & S. epidermidis & \\
\hline 12 & & & $x$ & S. epidermidis & E. coli \\
\hline & & & & Bacillus spp. & \\
\hline & & & & $\begin{array}{l}\text { S. } \\
\text { haemolyticus }\end{array}$ & \\
\hline 13 & $x$ & & & $\begin{array}{l}\text { Negative } \\
\text { culture }^{\neq}\end{array}$ & \\
\hline 14 & $x$ & & & $\begin{array}{l}\text { Negative } \\
\text { culture }^{\neq}\end{array}$ & \\
\hline 15 & $x$ & & & E. faecalis & \\
\hline
\end{tabular}

Abbreviations: HHA, Hip Hemiarthroplasty; ASB, asymptomatic bacteriuria; PJI, prosthetic joint infection; MSSA, methicillin susceptible $S$. aureus; MRSA, methicillin resistant $S$. aureus, ESBL producer, extended spectrum beta-lactamase producer

* This patient was diagnosed with a postoperative UTI caused by E. coli ESBL producer. 
${ }^{\neq}$Although purulence was observed at surgical debridement in those 2 cases, both under broad-spectrum antibiotic treatment at that time, cultures were negative.

Table 5. Univariate analysis of risk factors for early-PJI (ITT analysis) 


\begin{tabular}{|c|c|c|c|c|}
\hline \multirow[t]{4}{*}{ Risk factor } & \multirow{2}{*}{\multicolumn{2}{|c|}{$\begin{array}{l}\text { Patients, No. (\%) } \\
\mathrm{N}=594\end{array}$}} & \multicolumn{2}{|c|}{ Univariable Analysis } \\
\hline & & & & \\
\hline & $\begin{array}{l}\text { No HHA } \\
\text { infection }\end{array}$ & $\begin{array}{l}\text { HHA } \\
\text { infection }\end{array}$ & \multirow[t]{2}{*}{$\begin{array}{l}P \\
\text { value }\end{array}$} & \multirow[t]{2}{*}{ OR $(95 \% \mathrm{Cl})$} \\
\hline & $N=579,100 \%$ & $N=15,100 \%$ & & \\
\hline Age, mean (SD), y & $84.3(8.4)$ & $85.1(5.0)$ & \multirow[t]{2}{*}{0.7163} & \multirow{2}{*}{$\begin{array}{l}1.01 \\
(0.95 ; 1: 08)\end{array}$} \\
\hline Age, median (Q1-Q3), y & $\begin{array}{l}85.96 \\
(80.7 ; 89.7)\end{array}$ & $\begin{array}{l}86.0 \\
(81.1 ; 88.9\end{array}$ & & \\
\hline Female sex & 409 (70.6\%) & $11(73.3 \%)$ & 0.8210 & $\begin{array}{l}1.14 \\
(0.36 ; 3.64)\end{array}$ \\
\hline \multicolumn{5}{|l|}{ Comorbid conditions } \\
\hline Preoperative ASB & $148(25.6 \%)$ & $4(26.7 \%)$ & 0.9228 & $\begin{array}{l}1.06 \\
(0.33 ; 3.38)\end{array}$ \\
\hline BMI mean (SD) & $24.3(3.8)$ & $25.6(2.5)$ & \multirow[t]{2}{*}{0.2712} & \\
\hline Median (Q1-Q3), kg/m2 & $\begin{array}{l}24.2 \\
(21.7 ; 26.5)\end{array}$ & $\begin{array}{l}25.9 \\
(22.9 ; 27.3)\end{array}$ & & \\
\hline Obesity & $22(6.1 \%)$ & $1(9.1 \%)$ & 0.5103 & 1.00 \\
\hline \multicolumn{5}{|l|}{$(\mathrm{BMI} \geq 30 \mathrm{~kg} / \mathrm{m} 2)$} \\
\hline Ischemic heart disease & $48(8.3 \%)$ & $1(6.7 \%)$ & 0.8205 & $\begin{array}{l}0.79 \\
(0.10 ; 6.13)\end{array}$ \\
\hline Dementia & $161(27.1 \%)$ & $7(46.7 \%)$ & 0.1197 & $\begin{array}{l}2.27(0.81 ; \\
6.35)\end{array}$ \\
\hline Cirrhosis & $11(1.9 \%)$ & $1(6.7 \%)$ & 0.2270 & $\begin{array}{l}3.68 \\
(0.44 ; 30.51)\end{array}$ \\
\hline Diabetes & $147(25.4 \%)$ & $4(26.7 \%)$ & 0.9138 & $\begin{array}{l}1.07 \\
(0.33 ; 3: 40)\end{array}$ \\
\hline \multicolumn{5}{|l|}{ Charlson index score* } \\
\hline mean (SD) & $5.7(2.0)$ & $6.4(2.9)$ & \multirow[t]{2}{*}{0.2198} & \multirow{2}{*}{$\begin{array}{l}1.15 \\
(0.92 ; 1.44)\end{array}$} \\
\hline median (Q1-Q3) & $6.00(4,0 ; 7.0)$ & $6.0(4.0 ; 7.0)$ & & \\
\hline Immunosuppressors** & 32 /5.5\%) & $0(0 \%)$ & 0.3492 & $\begin{array}{l}1.00(1.00 \\
1.00)\end{array}$ \\
\hline Malignancy & $40(6.9 \%)$ & $3(20 \%)$ & 0.0682 & $\begin{array}{l}3.37 \\
(0.91 ; 12.43)\end{array}$ \\
\hline Anticoagulant treatment & $136(23.5 \%)$ & $5(33.3 \%)$ & 0.3659 & $\begin{array}{l}1.63 \\
(0.55 ; 4.84)\end{array}$ \\
\hline Antiplatelet treatment & $\begin{array}{r}171(29.5 \%) \\
\text { Page } 19 / 22\end{array}$ & $3(20 \%)$ & 0.4258 & 0.60 \\
\hline
\end{tabular}


$(0.17 ; 2.14)$

Days since admission to HHA

\begin{tabular}{|c|c|c|c|c|}
\hline mean $(\mathrm{SD})$ & $4.26(4.8)$ & $4.7(2.9)$ & \multirow[t]{2}{*}{0.7412} & \multirow{2}{*}{$\begin{array}{l}1.01 \\
(0.93 ; 1.10)\end{array}$} \\
\hline median (Q1-Q3) & $3.00(2.0 ; 5.0)$ & $\begin{array}{l}4.00(3.0 \\
6.0)\end{array}$ & & \\
\hline $\begin{array}{l}\text { since admission to } \mathrm{HHA}>75^{\text {th }} \\
\text { entile }\end{array}$ & 113 (19.5\%) & $5(33.3 \%)$ & 0.1957 & $\begin{array}{l}2.06 \\
(0.69 ; 6.14)\end{array}$ \\
\hline
\end{tabular}

Duration of HHA surgery

mean (SD), min

$93.97(25.57)$

$100.0(17.3)$

0.6863

1.01

median (Q1-Q3), min

90 (75.0;

115.0)

90 (90.0;

120.0)

Duration of HHA surgery

$28(24.6 \%)$

$1(33.3 \%)$

0.7302

1.54

$(0.13 ; 17.58)$

$>75^{\text {th }}$ percentile

Antibiotic Cemented HHA

$372 / 568$

$(65.6 \%)$

$9 / 15(60 \%)$

0.7351

0.83

$(0.29 ; 2.38)$

HHA dislocation

$13(2.2 \%)$

$1(6.7 \%)$

0.2901

3.11

$(0.38 ; 25.45)$

Any postoperative infection

$36(6.2 \%)$

$4(26.7 \%)$

0.0052

5.48

$(1.66 ; 18.08)$

Unless otherwise specified, data represent No. (\%) of patients.

Abbreviations: PJI, prosthetic joint infection; ITT, intention to treat analysis; HHA, hip hemiarthroplasty; $\mathrm{BMI}$, body mass index; $\mathrm{ASB}$, asymptomatic bacteriuria; $\mathrm{OR}$, odds ratio; $\mathrm{Cl}$, confidence interval; $\mathrm{SD}$, standard deviation.

* Charlson index score is adjusted by age

** Immunosuppressors includes steroids, classic immunosuppressors (ie: methotrexate, azathioprine, mycophenolate), biological drugs and chemotherapy

$\mathrm{N} / \mathrm{N}$ with data available when appropriate

\section{Figures}




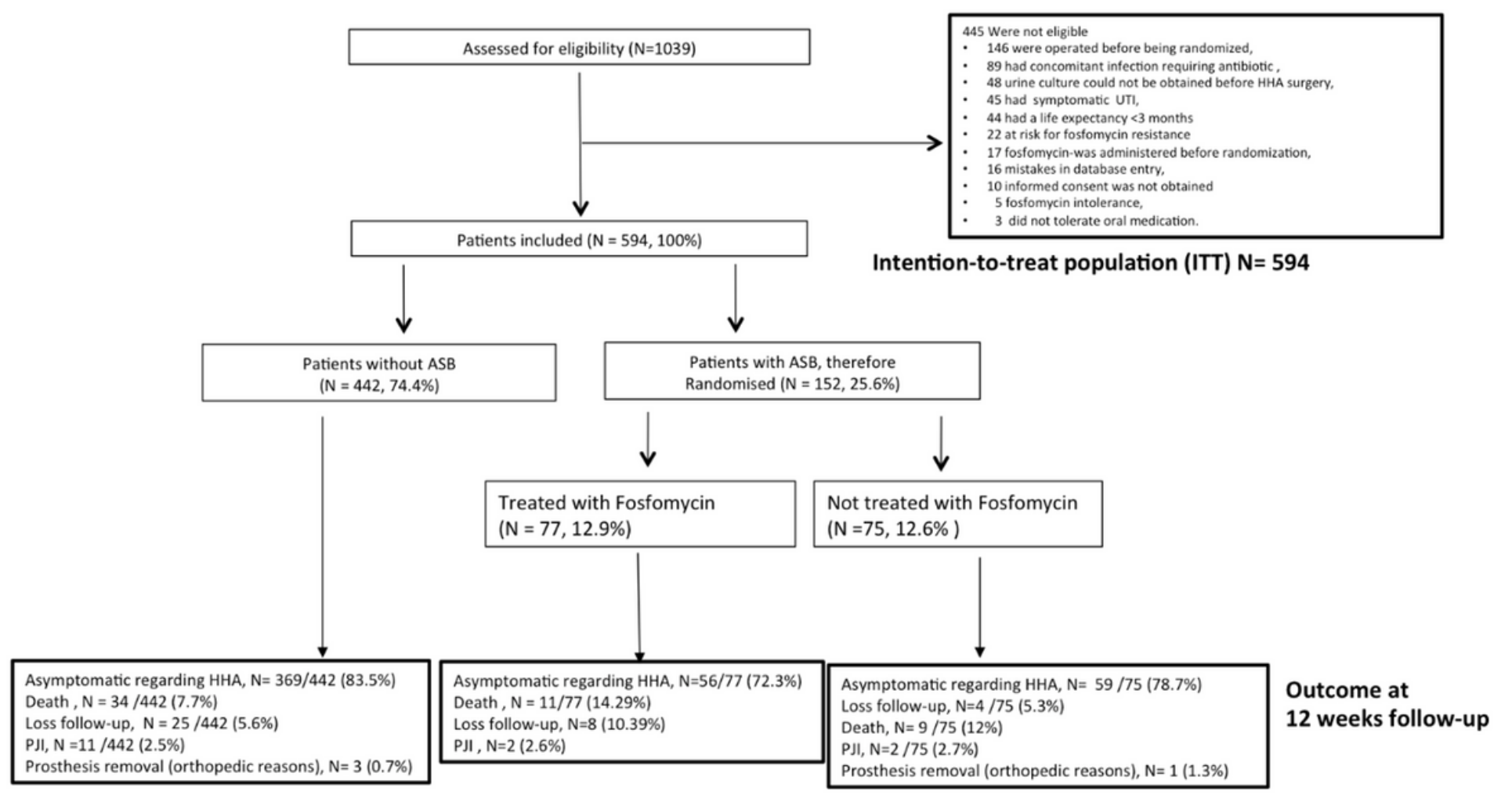

\section{Figure 1}

Overall flow chart and outcome of patients included in BARIFER clinical trial (ITT analyses), N= 594 . Abbreviations: ITT, intention to treat; UTI, urinary tract infection; ASB, asymptomatic bacteriuria; PJI, periprosthetic joint infection. 22 patients with ASB were considered at risk for Fosfomycin resistance as they were under chronic antibiotic prophylaxis with Fosfomycin-trometamol for recurrent cystitis. Therefore, they were not randomized. 


\section{Time early-PJI (Intention to Treat) \\ Patients}

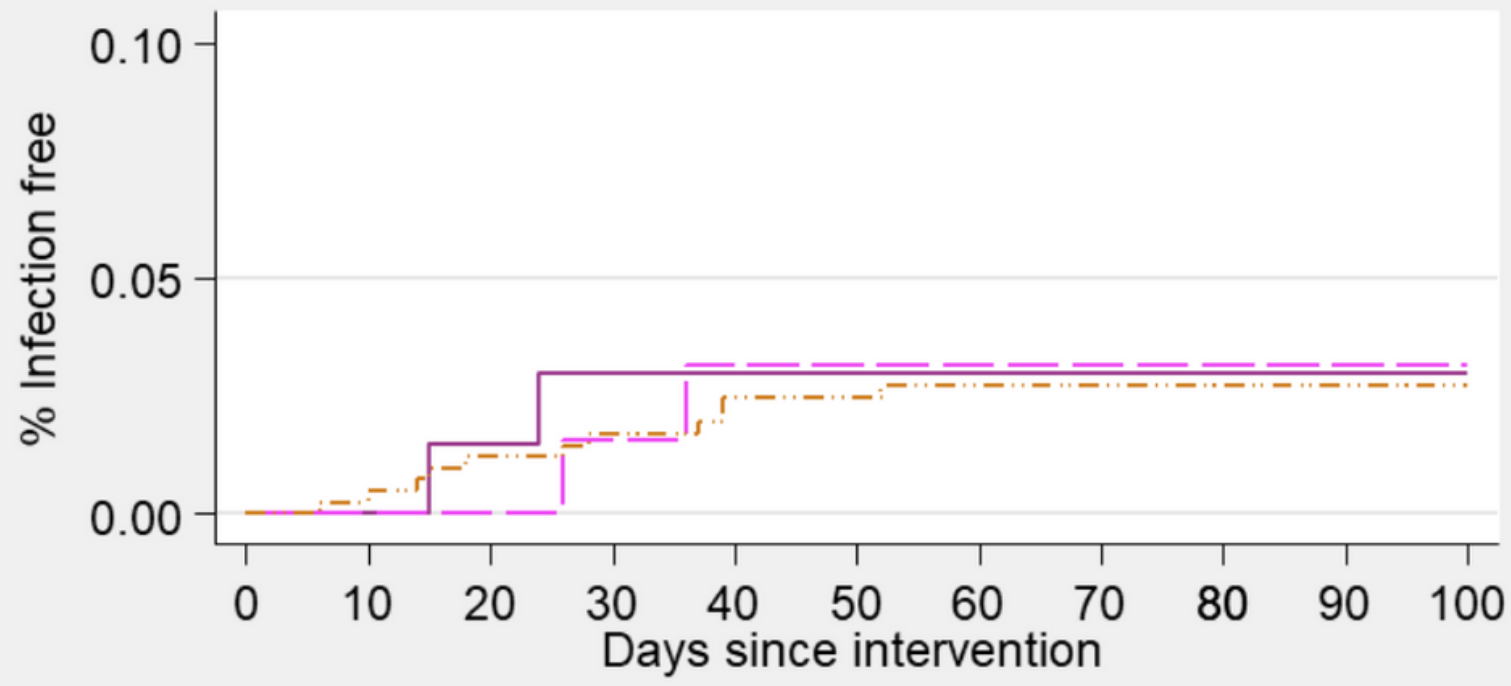

Number at risk

With ASB not treated with fosfomycin With ASB treated with fosfomycin

Without ASB

$\begin{array}{ccccccccccccccccccccc}74 & (0) & 69 & (1) & 66 & (1) & 65 & (0) & 65 & (0) & 63 & (0) & 63 & (0) & 63 & (0) & 60 & (0) & 44 & (0) & 8 \\ 73 & (0) & 69 & (0) & 67 & (1) & 62 & (1) & 61 & (0) & 56 & (0) & 55 & (0) & 54 & (0) & 52 & (0) & 41 & (0) & 10 \\ 430 & (1) & 419 & (4) & 411 & (2) & 400 & (3) & 389 & (0) & 384 & (1) & 375 & (0) & 368 & (0) & 359 & (0) & 283 & (0) & 53\end{array}$

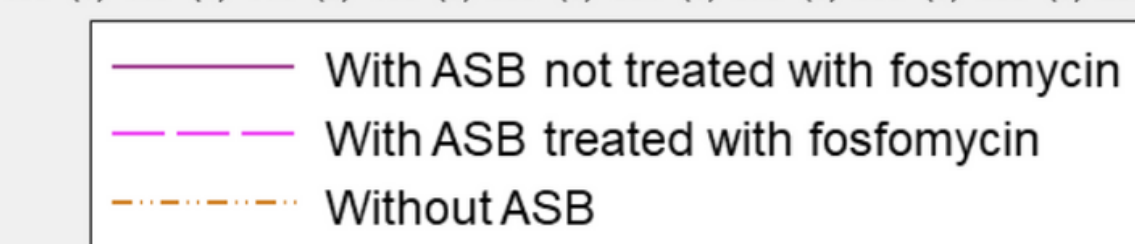

$P$ value $=0.9790$

Figure 2

Distribution of the time to early-PJI according to study group. Abbreviations: Early Periprosthetic Joint Infection

\section{Supplementary Files}

This is a list of supplementary files associated with this preprint. Click to download.

- BriefreportBARIFERSupTable1EJCMID.docx

- Newsupplementarytable2.EJCMID.docx

- BriefreportBARIFER.SupTable3.EJCMID.docx

- Briefreport.EJCMIDCONSORTChecklist.doc 